\title{
Ekonomi Versus Pemulihan Kesehatan: Telaah Rasionalitas Prioritas Kebijakan Pemerintah Indonesia dalam Krisis Pandemi Covid-19
}

\author{
Bangkit Adhi Wiguna', Bara Muhammad Setiadi², \\ Dhivana Anarchia Ria Lay ${ }^{3}$
}

\begin{abstract}
Abstrak
Artikel ini bertujuan untuk menganalisis justifikasi pemerintah Indonesia yang alih-alih mengedepankan isu kesehatan, justru memprioritaskan kebijakan pemulihan ekonomi dalam merespons krisis akibat pandemi Covid-19. Dalam menganalisis fenomena tersebut, kami menggunakan metode analisis data sekunder. Data yang dianalisis meliputi statistik resmi mengenai perubahan $P D B$ tahun 2020, publikasi lembaga riset, dan pemberitaan media massa terkait kebijakan ekonomi Indonesia pada masa pandemi. Teori utama yang digunakan untuk mengkaji pilihan kebijakan antara ekonomi dan kesehatan adalah teori pilihan rasional didukung dengan konsep makroekonomi untuk menjelaskan data mengenai ekonomi nasional Indonesia sepanjang tahun 2020. Temuan dan analisis menunjukkan bahwa institusi pemerintahan maupun non-pemerintahan mengeluarkan kebijakan regulasi atau pun deregulasi yang mengutamakan ekonomi daripada kesehatan.
\end{abstract}

Kata kunci: Pertumbuhan Ekonomi; Pandemi Covid-19; Pemulihan Ekonomi; Pemulihan Kesehatan; Kebijakan Publik; Pilihan Rasional

1 Penulis adalah mahasiswa program sarjana Departemen Politik dan Pemerintahan, Fisipol, UGM, Yogyakarta. Penulis bisa dihubungi melalui bangkit.adhi.wiguna@mail.ugm.ac.id

2 Penulis adalah mahasiswa program sarjana Departemen Politik dan Pemerintahan, Fisipol, UGM, Yogyakarta. Penulis bisa dihubungi melalui bara.setiadi@mail.ugm.ac.id

3 Penulis adalah mahasiswi program sarjana Departemen Politik dan Pemerintahan, Fisipol, UGM, Yogyakarta. Penulis bisa dihubungi melalui layarsya@mail.ugm.ac.id 


\section{PENDAHULUAN}

Tujuan artikel ini adalah untuk menganalisis rasionalitas pemerintah Indonesia yang memprioritaskan pemulihan ekonomi dalam merespons krisis yang diakibatkan oleh pandemi Covid-19. COVID-19 merupakan sebuah virus yang pertama kali ditemukan di Wuhan, Cina dan dengan sangat cepat menginfeksi jutaan manusia. Penyebaran yang eksponensial ini menyebabkan World Health Organisation (WHO) menyatakan wabah COVID-19 sebagai sebuah pandemi global pada 11 Maret 2020. Hal tersebut memaksa masyarakat berusaha menghentikan sebagian maupun seluruh aktivitas guna mencegah penyebaran virus COVID-19. Banyak negara yang kemudian menerapkan kebijakan lockdown selama berbulan-bulan untuk menekan laju penyebaran virus (Dunford et.al., 2020). Misalkan di daerah Asia, negara-negara seperti Nepal, Malaysia, India, Iran, Pakistan, Bangladesh, Uzbekistan, Timor Leste, dan Laos menerapkan lockdown nasional pada Maret-April 2020 (Dunford et.al., 2020). Ada pula negara-negara di Eropa, seperti Prancis, Jerman, Italia, Spanyol, Belgia, Swiss, Austria, Belanda, dan lain sebagainya menerapkan kebijakan serupa (Dunford et.al., 2020). 
Indonesia pun tidak terlepas dari ancaman virus COVID-19. Per tanggal 22 Desember 2020, total kasus COVID-19 di Indonesia sudah mencapai sekitar 678 ribu dengan korban jiwa sebanyak 20 ribu (Worldometer, 2020). Untuk menanggapi bahaya COVID-19, pemerintah Indonesia menerapkan kebijakan PSBB atau Pembatasan Sosial Berskala Besar (Kementerian Koordinator Bidang Pembangunan Manusia dan Kebudayaan Republik Indonesia, 2020). Kebijakan pembatasan hingga pelarangan pelaksanaan aktivitas masyarakat yang dilakukan oleh sebagian besar negara menyebabkan perekonomian dunia menurun drastis (World Bank, 2020).

\section{MEMPERDEBATKAN PRIORITAS KEBIJAKAN DI TENGAH KRISIS: KAJIAN PUSTAKA}

Menurut Weible et.al. (2020) pandemi COVID-19 tidak hanya memengaruhi sektor kesehatan, tetapi juga seluruh aspek kehidupan. Akibatnya, kebijakan pemerintah yang diambil untuk menanggulangi dampak dari COVID-19 sekaligus turut juga dipengaruhi oleh beberapa faktor selain kesehatan, seperti kelembagaan, budaya, ekonomi, dan politik. Dalam pengambilan keputusan pun, pemerintah harus mempertimbangkan 
berbagai harga sosial atau ekonomi yang setiap decision atau nondecision ciptakan.

Loayza \& Pennings (2020) secara eksplisit menyusun dikotomi antara menyelamatkan hidup dan menyelamatkan penghidupan di tengah pandemi. Oleh karena itu, sebuah pilihan harus dibuat antara kesehatan (menyelamatkan hidup) atau ekonomi (menyelamatkan penghidupan). Namun, menurut mereka beban dari pilihan tersebut dapat diringankan oleh kebijakan publik.

Loayza \& Pennings mengusulkan empat kebijakan dalam menghadapi COVID-19. Pertama, meningkatkan pengeluaran pemerintah dalam sektor kesehatan. Kedua, memberi pertolongan untuk masyarakat. Ketiga, menolong usaha yang terpengaruh. Keempat, melonggarkan sistem finansial. Korea Selatan dirujuk sebagai contoh dari negara yang menerapkan solusi ini dengan distribusi anggaran 10 persen untuk kesehatan, 25 persen untuk rumah tangga, dan 65 persen untuk usaha.

Walaupun Loayza \& Pennings tidak mengabaikan aspek ekonomi, solusi yang ditawarkan oleh mereka cenderung untuk mengutamakan aspek kesehatan. Hal tersebut dapat dilihat dari pengalokasian pengeluaran 
pemerintah dalam sektor kesehatan dan pertolongan finansial untuk menekan aktivitas secara umum. Alokasi dana dalam sektor kesehatan secara tidak langsung mengalihkan dana yang dapat dialokasikan ke sektor lain seperti pembangunan ekonomi.

Laporan dari Federal Reserve Bank of St. Louis juga menekan betapa pentingnya ekonomi dalam situasi pandemi. Merujuk kembali pada kasus Spanish Flu di Amerika, Thomas Garrett meninjau bahwa terdapat kebijakan lockdown di beberapa kota di Amerika yang tidak direncanakan secara efektif. Dalam jangka pendek, kebijakan lockdown justru menyakiti ekonomi, terutama dalam sektor bisnis.

Sementara itu, laporan tersebut tidak menemukan relasi yang kuat terhadap satu sisi untuk ekonomi dalam jangka panjang. Secara individu, asuransi juga merupakan hal yang penting saat masa pandemi karena asuransi jiwa dapat meminimalisasi dampak ekonomi pandemi bagi keluarga yang pencari nafkah utamanya terinfeksi virus. Faktor kesehatan juga ditopang oleh ekonomi. Infrastruktur kesehatan sebaik apapun tidak berguna jika tidak terjangkau atau tidak memiliki sistem ekonomi yang dapat menunjang infrastruktur kesehatan itu sendiri (Garrett, 2007). 


\section{TEORI PILIHAN RASIONAL UNTUK MEMAHAMI PRIORITAS KEBIJAKAN: SUATU KERANGKA TEORITIK}

Teori pilihan rasional merupakan pendekatan ilmu politik yang menggunakan logika ekonomi untuk menjelaskan fenomena sosial (Hindmoor \& Taylor, 2018: 39). Kunci dari logika ekonomi adalah berpikir secara deduktif, yaitu dari hal umum ke spesifik (Hindmoor \& Taylor, 2018: 40). Dalam ilmu ekonomi, hal umum digambarkan sebagai suatu fenomena sosial sedangkan hal spesifik sebagai asumsi perilaku aktor dalam fenomena sosial tersebut. Aktor lalu diasumsikan akan selalu merespons insentif dengan tindakan yang mudah diprediksi (Hindmoor \& Taylor, 2018: 41). Oleh karena itu, dalam memandang suatu fenomena, ilmu ekonomi berusaha memprediksi insentif yang melatarbelakangi suatu tindakan tertentu.

Dengan menggunakan logika ekonomi, teori ini berasumsi bahwa tiap aktor politik merupakan individu rasional yang akan memperjuangkan tujuan sesuai kepentingannya sendiri, bebas dari aspek politik yang diincar (Hindmoor \& Taylor, 2018: 39). Dalam konteks ini, aktor tidak harus berupa satu orang individu, tetapi juga bisa dalam bentuk kelompok. Misalkan, kelompok 
kepentingan, partai politik, pemerintah, dan lain sebagainya.

Kydd (2008: 427) menyajikan cabang yang spesifik mengenai pilihan rasional yang disebut sebagai methodological individualism and rational choice (MIRC). MIRC menggunakan dasar bahwa aktor yang berperan dalam fenomena adalah manusia dan tujuannya adalah untuk menjelaskan fenomena seperti perang dan kemiskinan menggunakan perilaku individu. MIRC berargumen bahwa setiap fenomena harus memiliki dasar mikro yang dapat teragregasi menjadi fenomena makro. Oleh karena itu, MIRC beranggap bahwa fenomena terjadi dari tingkat mikro lalu ke makro dan tidak sebaliknya, hal ini termasuk bagaimana aktor dianggap sebagai variabel eksogen dan mengabaikan proses sosialisasi.

\section{KERANGKA KONSEPTUAL UNTUK MEMAHAMI RASIONALITAS \\ PEMULIHAN EKONOMI}

\section{Pendapatan Domestik Bruto (PDB)}

Untuk memahami insentif, kepentingan pribadi, dan rasionalitas aktor dalam perumusan kebijakan andemi COVID-19, tulisan ini menggunakan teori pendapatan 
nasional, secara spesifik perhitungan Pendapatan Domestik Bruto (PDB). PDB merupakan sebuah angka yang menyimpulkan seluruh kegiatan ekonomi dalam suatu satuan tertentu (USD atau IDR) dalam jangka waktu tertentu, biasanya satu tahun (Mankiw, 2009: 18). PDB memberikan gambaran besaran, kesehatan, dan pertumbuhan ekonomi dari suatu negara. Semakin besar selisih antara PDB suatu tahun dengan PDB tahun sebelumnya, maka semakin besar pula pertumbuhan ekonomi negara tersebut (Mankiw, 2009: 23).

Menurut Mankiw, PDB terdiri dari dua pendekatan: income approach dan expenditure approach. Dalam income approach, PDB dianggap sebagai keseluruhan pendapatan yang diterima dalam suatu perekonomian dari hasil transaksi barang maupun jasa. Sedangkan, dalam expenditure approach, $\mathrm{PDB}$ dianggap sebagai keseluruhan pengeluaran yang dikeluarkan dalam suatu perekonomian untuk mendapatkan barang atau jasa.

Dua pendekatan ini harus bersifat setara karena kenaikan pendapatan satu pihak dalam suatu transaksi akan mengakibatkan kenaikan pengeluaran yang sama pula pada sisi lain (Mankiw, 2009: 18). Tulisan ini menganalisis pertumbuhan ekonomi Indonesia di tengah pandemi dengan menggunakan expenditure approach. 
Secara matematis, expenditure approach dapat dituliskan dengan rumus:

$$
Y=C+I+G+N X
$$

Dengan variabel Y (yield) mewakilkan pendapatan nasional (PDB), variabel C (consumption) mewakili pengeluaran rumah tangga untuk mendapatkan barang dan jasa, variabel I (investment) mewakili jumlah pengeluaran untuk barang dan jasa yang akan digunakan pada masa depan dalam bentuk modal maupun inventaris, variabel G (government expenditure) mewakili pengeluaran atau belanja pemerintah yang mendapatkan timbal balik berupa barang atau jasa, dan variabel NX (net export) mewakilkan nilai ekspor bersih sebagai konsumsi barang domestik dalam negara lain (Mankiw, 2009: 27).

\section{Model Konsumsi Agregat}

Konsumsi agregat merupakan keseluruhan konsumsi yang dilakukan oleh rumah tangga masyarakat. Konsumsi agregat bisa dimodelkan sebagai berikut:

$$
C=\bar{C}+c Y
$$

Dengan variabel C (consumption) mewakilkan konsumsi masyarakat, variabel $\overline{\mathrm{C}}$ (autonomous 
consumption) mewakili konsumsi otonom, yaitu konsumsi yang harus dipenuhi bebas dari pendapatan yang diterima, variabel c (Marginal Propensity to Consume), sebuah bilangan antara o dan 1 yang mewakili kecenderungan masyarakat untuk mengonsumsi untuk setiap kenaikan pendapatan, dan variabel $\mathrm{Y}$ (disposable income) mewakili pendapatan setelah pajak langsung (Mankiw, 2009: 497). Rumus ini mengikuti postulasi Keynes bahwa faktor utama yang menentukan pengeluaran rumah tangga adalah pendapatan bersih ceteris paribus (Mankiw, 2009: 496).

Disposable Income (Yd) adalah pendapatan masyarakat yang dapat ditukar dengan barang atau jasa. Secara matematis, disposable income dapat dituliskan dengan rumus:

$$
\text { Yd = PI - Personal Tax (PPh) - Non Tax Payment }
$$

Dengan variabel PI (Personal Income) mewakilkan pendapatan pribadi dan variabel Personal Tax mewakili pajak penghasilan ( $\mathrm{PPh}$ ) dan variabel Non Tax Payment mewakili pembayaran non pajak seperti retribusi. Melalui persamaan di atas, bisa dilihat bahwa kebijakan pengurangan pajak penghasilan ( $\mathrm{PPh}$ ) akan meningkatkan disposable income (Yd). 
Di lain sisi, PI atau personal income adalah total pendapatan pribadi seseorang. PI dirumuskan sebagai berikut:

$$
P I=N N I+T F-(L T+P P+A+J S)
$$

Dengan variabel NNI (net national income) mewakilkan pendapatan nasional bersih/netto, variabel TF (transfer payment) mewakilkan pemberian dana tanpa timbal balik dari pemerintah (BLT, dana pensiun, beasiswa, hibah, dsb.), variabel LT mewakilkan laba ditahan oleh perseroan, variabel PP mewakilkan pajak perseroan, variabel A mewakilkan asuransi, dan variabel JS mewakilkan iuran jaminan sosial (Mankiw, 2009: 31). Kebijakan pemerintah yang memberikan bantuan tunai langsung dan/atau sejenisnya tanpa menerima timbal balik akan meningkatkan transfer payment. Peningkatan transfer payment akan diikuti dengan peningkatan personal income pula. Peningkatan personal income akan meningkatkan disposable income.

Ketika disposable income meningkat, maka daya beli masyarakat juga turut meningkat. Hasilnya, konsumsi masyarakat (C) juga akan meningkat. Jika konsumsi masyarakat (C) meningkat maka pendapatan nasional/ PDB (Y) juga akan meningkat. 


\section{POLEMIK PRIORITAS KESEHATAN VS \\ EKONOMI DI INDONESIA: MEMETAKAN \\ BASIS KEDUA NARASI}

\section{Ekonomi: Urgensi di Level Mikro}

Melalui pandangan teori ekonomi mikro, perputaran roda ekonomi yang semakin cepat di tengah pemulihan pandemi dapat diamati melalui berbagai aktivitas ekonomi jual-beli dalam level paling sederhana sekalipun. Misalkan, kegiatan jual-beli di pasar-pasar tradisional dapat menjadi indikator berjalannya kembali roda perekonomian. Melansir dari Republika, terjadi lonjakan jumlah pengunjung Pasar Gede di Solo setelah diberlakukannya kebijakan new normal. Kompas juga melaporkan hal serupa di Yogyakarta yang jumlah pengunjung tempat wisata Malioboro sudah mulai berangsur normal seperti sebelum pandemi.

Selain itu, banyaknya laporan mengenai pelanggaran PSBB juga merupakan indikasi dari meningkatnya kegiatan ekonomi masyarakat. Oleh sebab itu, bagaimana pun kegiatan ekonomi merupakan aspek yang sama vitalnya dengan kesehatan. Oleh karena itu, melakukan kegiatan ekonomi yang terhalang oleh PSBB paling tidak menjadi motif yang paling dominan untuk melanggar PSBB. Dengan demikian, naiknya angka 
pelanggaran PSBB dapat diasumsikan sebagai naiknya kegiatan ekonomi masyarakat.

Di DKI Jakarta sendiri, per 18 Mei 2020, tercatat ada lebih dari 1.200 usaha yang melanggar PSBB, yang melibatkan lebih dari 17 ribu karyawan (Kompas, 2020). Laporan juga menunjukkan bahwa sejak PSBB, tidak tercatat adanya penurunan kunjungan dalam restoran maupun pusat perbelanjaan, kunjungan ke tempattempat ini justru meningkat hingga 78 persen (CNN Indonesia, 2020). Klaster tempat makan pun mulai bermunculan. Sebuah warung bakmi di Yogyakarta terpaksa tutup sementara karena salah satu pegawainya positifCOVID-19 dan menularkannya ke setidaknya enam orang lainnya (Pangaribowo \& Kontributor Yogyakarta, 2020). Begitu pula dengan sebuah warung makan di daerah Klaten, Jawa Tengah dimana ditemukan enam orang positif COVID-19 dan 21 orang kontak erat (Syauqi, 2020). Begitu pula sebuah rumah makan di Semarang yang juga dilaporkan menjadi klaster baru dengan 20 orang dinyatakan positif COVID-19 (Nazzala, 2020). Berbagai bentuk pelanggaran tersebut menunjukkan bahwa di level mikro, pandemi sekalipun tidak mampu menghentikan masyarakat untuk melakukan aktivitas ekonomi. 


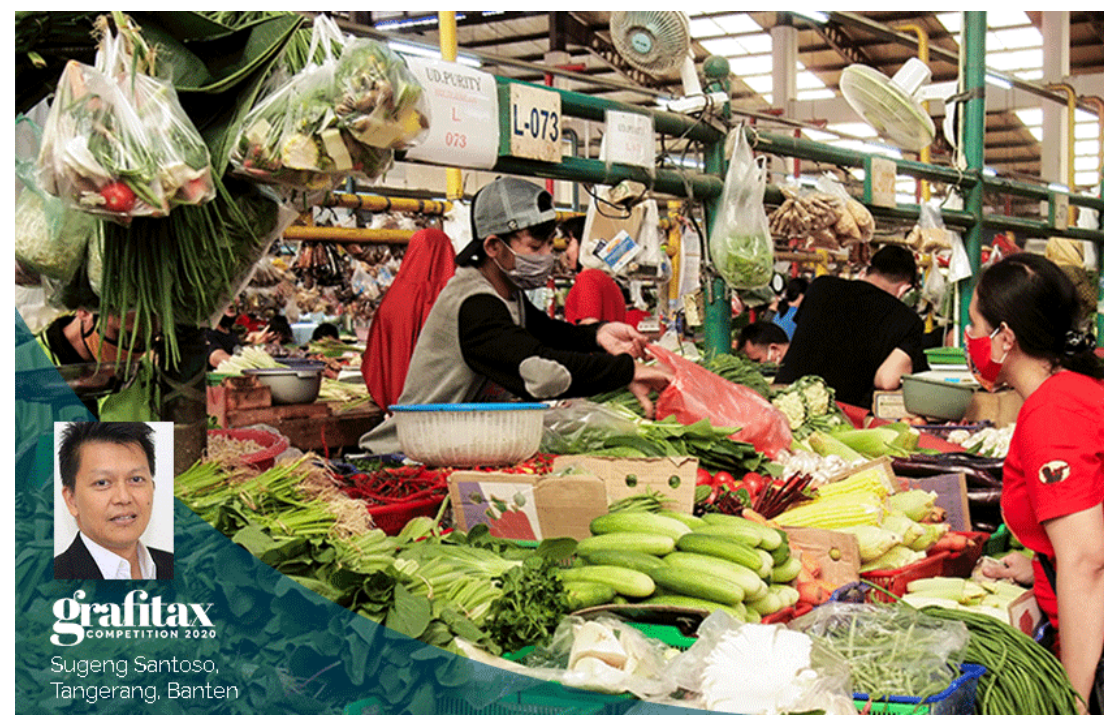

Sumber: https://news.ddtc.co.id/ekonomi-terus-bergerak26137?page_y $=O$

Hal lain yang bisa menguatkan argumen bahwa roda ekonomi tetap tidak terbendung terdapat dalam kehidupan sehari-hari. Setiap hari, masih banyak pasar tradisional yang beroperasi di tengah pandemi (Maskur, 2020). Kegiatan ini ditangkap secara sempurna melalui foto yang berjudul Ekonomi Terus Bergerak oleh Sugeng Santoso. Dalam foto tersebut, tampak beberapa pembeli dan penjual yang menggunakan masker dan berjaga jarak selama melakukan transaksi jual-beli. Foto sederhana ini menunjukkan bahwa masyarakat memilih untuk tidak meninggalkan kegiatan ekonomi dan justru 
"berdamai" dengan pandemi. Foto tersebut merupakan bukti nyata tidak terbendungnya roda ekonomi.

\section{Ekonomi: Urgensi di Level Makro}

Hal yang serupa dapat juga diamati melalui lensa ekonomi makro. Menurut laporan Global Economic Prospects pada Juni 2020, pandemi COVID-19 diperkirakan akan mengakibatkan kontraksi Pendapatan Domestik Bruto (PDB) global sebesar 5,2 persen, yang merupakan resesi terdalam sejak Perang Dunia II (World Bank, 2020). Resesi perekonomian secara global ini mulai kentara di kuartal pertama dan kedua 2020. Misalnya, kondisi perekonomian Cina yang mengalami pertumbuhan PDB negatif sebesar 10 persen pada kuartal pertama ( $\mathrm{PwC}$ China, 2020) atau Amerika Serikat yang turut mengalami pertumbuhan PDB negatif pada kuartal pertama sebesar 5 persen dan lagi pada kuartal kedua sekitar 30 persen (BEA, 2020). Perekonomian Indonesia juga demikian. Indonesia mencatat PDB kuartal pertama 2020 di angka positif 2,97 persen, menurun nyaris setengahnya jika dibandingkan dengan PDB pada kuartal keempat 2019 (Asia Perspective, 2020). Kemudian, pada kuartal kedua dan ketiga tahun 2020 PDB Indonesia tercatat menurun di angka negatif 5,32 persen dan negatif 3,49 persen (Trading Economics, 2020). 
Berbagai sektor ekonomi, besar maupun kecil, juga tidak luput dari serangan pandemi COVID-19. Laporan dari Financial Times menyebutkan bahwa setidaknya ada 157 perusahaan yang telah mengajukan bangkrut pada tahun ini (Afriyadi, 2020). Sementara itu, pada Agustus 2020, Badan Pusat Statistik (BPS) mencatat bahwa sebanyak 29,12 juta penduduk Indonesia terdampak pandemi COVID-19, mulai dari pengurangan jam kerja hingga Pemutusan Hubungan Kerja (PHK) (Victoria, 2020).

Meskipun demikian, berdasarkan data dari World Bank, perekonomian global sudah mulai pulih sekalipun pandemi semakin memburuk. Peningkatan aktivitas ekonomi global terlihat di bidang manufaktur dan servis. Global composite Purchasing Managers Index (PMI) JP Morgan mencatat peningkatan dari 52,5 menjadi 53,3 pada bulan September-Oktober 2020. Global composite PMI menggambarkan sektor manufaktur dan servis global berdasarkan survey bulanan purchasing executives dari 32 perusahaan yang menyumbang lebih dari 85 persen PDB dunia (Mypivots, n.d.). 


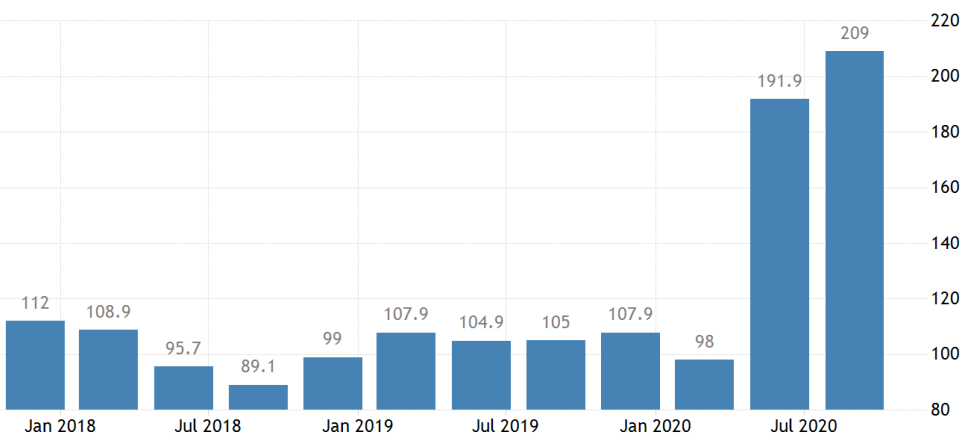

SOURCE: TRADINGECONOMICS.COM | INVESTMENT COORDINATING BOARD OF THE REPUBLIC OF INDONESIA (BKPM)

Sumber: https://tradingeconomics.com/indonesia/foreign-directinvestment\#: :text=Foreign\%2oDirect\%2OInvestment\%20in\%2O Indonesia,the\%2ofirst\%20quarter\%20of\%202010.

FOREIGN DIRECT INVESTMENT (FDI) REALIZATION BASED ON SECTOR JULY - SEPTEMBER (QUARTER III) 2020

\begin{tabular}{|c|c|c|c|}
\hline \multirow{2}{*}{ No. } & \multirow{2}{*}{ Sector } & \multicolumn{2}{|r|}{2020} \\
\hline & & Project & Investment (US\$ Million) \\
\hline 1 & Metal, Except Machinery and Equipment Industry & 468 & $1,631.5$ \\
\hline 2 & Transportation, Warehouse, and Telecommunication & 442 & 994.6 \\
\hline 3 & Electricity, Gas, and Water Supply & 261 & 916.1 \\
\hline 4 & Housing, Industrial Estate, and Office Building & 682 & 604.4 \\
\hline 5 & Chemical and Pharmaceutical Industry & 697 & 595.4 \\
\hline 6 & Mining & 372 & 569.4 \\
\hline 7 & Food Industry & 1,129 & 344.9 \\
\hline 8 & Machinery, Electronic, Medical Instrument, Precision, Optical, and Watch Industry & 607 & 282.0 \\
\hline 9 & Other Services & 2,688 & 247.9 \\
\hline 10 & Vehicle and Other Transportation Industry & 550 & 192.0 \\
\hline 11 & Food Crops, Plantations, and Livestock & 508 & 132.8 \\
\hline 12 & Paper and Printing Industry & 209 & 116.5 \\
\hline 13 & Hotel and Restaurant & 1,849 & 114.9 \\
\hline 14 & Rubber and Plastic Based Goods Industry & 429 & 110.5 \\
\hline 15 & Other Industries & 397 & 109.2 \\
\hline 16 & Trade and Reparation & 3,587 & 95.7 \\
\hline 17 & Leather Goods and Footwear Industry & 145 & 85.3 \\
\hline 18 & Textile Industry & 486 & 75.3 \\
\hline 19 & Non Metallic Mineral Industry & 150 & 64.4 \\
\hline 20 & Wood Industry & 155 & 59.2 \\
\hline 21 & Construction & 230 & 15.6 \\
\hline 22 & Forestry & 46 & 9.6 \\
\hline 23 & Fishery & 183 & 2.8 \\
\hline & Total & 16,270 & $7,370.6$ \\
\hline
\end{tabular}

Sumber: https://www.bkpm.go.id/images/uploads/investasi_ indonesia/file/FDI_Realization_Based_on_Sector_Q3_2020.pdf. 
Peningkatan ekosistem investasi juga mulai terlihat pada bulan November 2020 dengan index Sentix yang menyentuh angka positif untuk pertama kalinya dalam sembilan bulan terakhir (World Bank, 2020). Index Sentix merepresentasikan ekspektasi pasar investor untuk satu bulan ke depan. Di Indonesia, investasi asing secara langsung (direct foreign investment) telah naik sebesar 1,1 persen menjadi Rp106,1 triliun di kuartal ketiga 2020 (Trading Economics, 2020.). Mayoritas investasi asing berasal dari Singapura, Cina, dan Jepang dengan sektor penerima investasi paling banyak adalah industri logam, transportasi, pergudangan, dan telekomunikasi (Trading Economics, 2020.). Di sisi lain, total keseluruhan investasi, asing maupun domestik, naik sebesar 1,6 persen (Trading Economics, 2020.). Investasi di Indonesia diproyeksikan akan semakin meningkat akibat sejumlah kebijakan deregulasi yang akan diterapkan di masa depan. Salah satunya adalah UU Cipta Kerja yang mensinyalkan terbukanya Indonesia untuk investasi serta penyederhanaan proses penetapan SNI (World Bank, 2020: 34). 


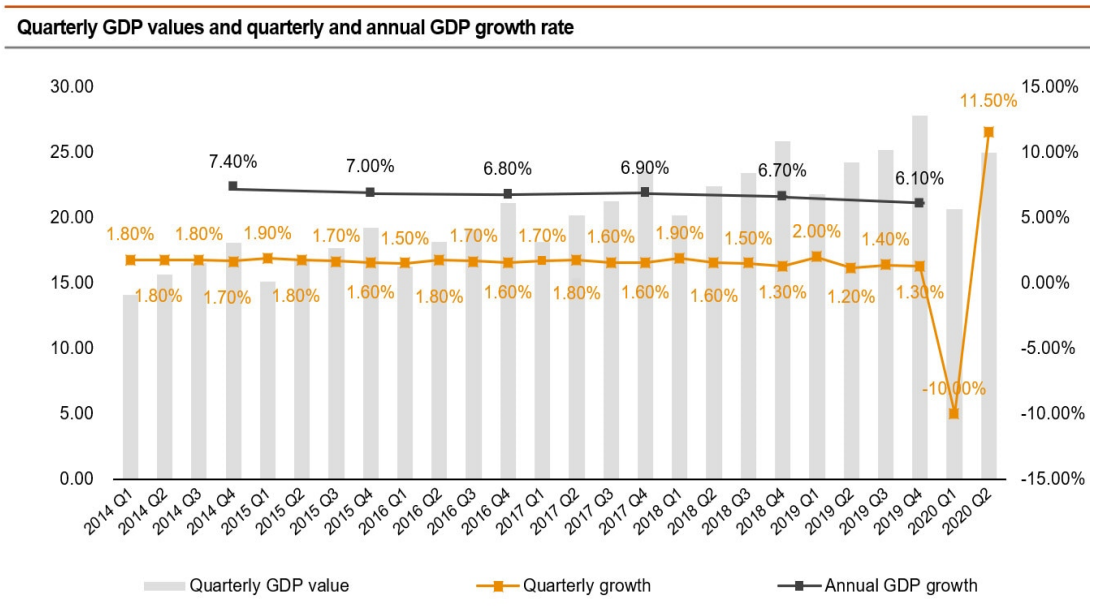

Source of data: Unless otherwise stated, economic data is from the National Bureau of Statistics, Wind and financial data from the People's Bank of China.

Sumber: https://www.pwccn.com/en/research-and-insights/chinaeconomic-quarterly-q2q3-202O.html.

Pemulihan perekonomian global juga bisa dilihat melalui PDB kuartalan di negara-negara tertentu. Misalnya, PDB Amerika Serikat yang meningkat sebesar positif 33,1 persen pada kuartal ketiga 2020 (BEA, 2020). Selain itu, PDB Cina juga tercatat sudah mulai pulih sejak kuartal kedua dengan peningkatan sebesar positif 11,5 persen ( $\mathrm{PwC}$ China, 2020). Indonesia juga diperkirakan akan mengalami peningkatan PDB sebesar 2,59 persen dari negatif 3,49 persen pada kuartal ketiga menjadi negatif 0,9 persen pada kuartal keempat 2020 (Hendartyo, 2020). Walaupun PDB Indonesia belum 
berada di angka positif, data di atas menunjukkan bahwa tetap terjadi pertumbuhan ekonomi selama pandemi.

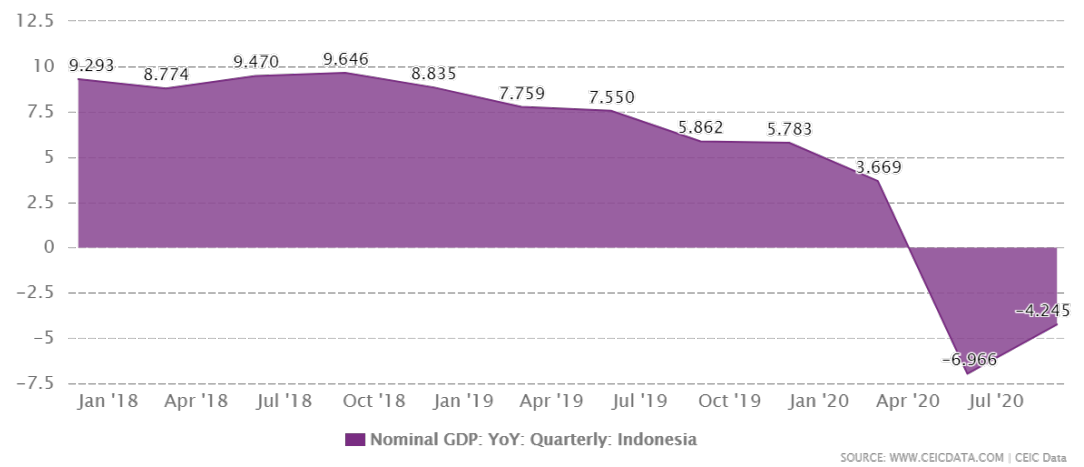

Sumber: https://www.ceicdata.com/en/indicator/indonesia/ nominal-gdp-growth

\section{Kesehatan: Syarat Aktivitas Berjalan}

Siti Setiati dan Muhammad K. Azwar (2020: 197) memiliki opini yang berbeda. Mereka berpendapat bahwa kesehatan seharusnya mendapat prioritas lebih daripada ekonomi. Menurut mereka, penanganan kesehatan yang buruk pada akhirnya akan berimbas kepada ekonomi yang buruk pula. Argumen tersebut dibuktikan dengan berbagai temuan terkait pandemi Spanish Flu pada tahun 1918. Pada masa pandemi Spanish Flu, beberapa daerah yang memiliki indikator kesehatan buruk mengalami penurunan dalam aktivitas 
ekonomi penduduknya. Penurunan tersebut terjadi pada sisi supply dan demand. Kesehatan buruk juga diperkirakan menurunkan PDB sebesar 15 persen tiap tahunnya (Setiati \& Azwar, 2020: 197). Menurut Setiati dan Azwar, apa yang terjadi pada pandemi Spanish Flu satu abad lalu dapat dijadikan pelajaran untuk penanganan pandemi COVID-19.

Dalam tulisan tersebut, Taiwan dijadikan contoh sukses dalam menangani pandemi melalui kebijakan lockdown, terutama mengingat letak geografisnya yang dekat dengan Cina, tempat wabah COVID-19 pertama kali muncul. Di Taiwan, penanganan pandemi COVID-19 dilakukan dengan cepat dan tegas sehingga sejak April 2020, penyebaran virus sudah terkontrol (Setiati \& Azwar, 2020: 197).

Pada Juli 2020, PMI (Purchasing Manufacturing Index) Taiwan meningkat ke titik tertingginya setelah enam bulan (Setiati \& Azwar, 2020: 197). PDB Taiwan juga meningkat dari negatif o,71 persen (kuartal kedua) menjadi positif 3,91 persen (kuartal ketiga) (Trading Economics, 2020). Begitu pula dengan Selandia Baru yang sudah menyatakan negaranya bebas COVID-19 sejak Juni 2020 (BBC, 2020). Ditinjau dari pertumbuhan perekonomiannya, PDB Selandia Baru meningkat dari negatif 11 persen (kuartal kedua) menjadi positif 14 persen 
(kuartal ketiga) (Stats NZ, 2020). Dengan demikian, Setiati dan Azwar berpendapat bahwa memprioritaskan kesehatan dapat memulihkan perekonomian.

\section{EKONOMI SEBAGAI PANGLIMA: RASIONALITAS NEGARA MEMPRIORITASKAN PEMULIHAN EKONOMI DI TENGAH PANDEMI}

Di Indonesia, konsumsi masyarakat (C) menyumbang lebih dari 50 persen pendapatan nasional (Y) atau PDB negara sehingga meningkatkan variabel $\mathrm{C}$ menjadi kunci pulihnya perekonomian Indonesia (Jayani, 2019). Upaya pemerintah Indonesia untuk mengerem pertumbuhan minus PDB nasional adalah dengan meningkatkan pengeluaran pemerintah $(G)$ dan mengalokasikannya ke kebijakan yang mampu meningkatkan daya beli/ konsumsi masyarakat. Sederhananya, peningkatan konsumsi (C) dan pengeluaran pemerintah (G) akan meningkatkan pendapatan nasional (Y).

$$
Y=C+I+G+N X
$$

Peningkatan pengeluaran pemerintah dilakukan melalui berbagai kebijakan. Misalnya, kebijakan Padat Karya Tunai (PKT) atau cash for work yang diterapkan 
di daerah-daerah pedesaan, terutama yang miskin (Kompas, 2020). Dilansir dari laman resmi Direktorat Jenderal Perimbangan Keuangan, PKT adalah kegiatan pemberdayaan masyarakat desa, khususnya yang miskin dan termarjinalkan dengan mengutamakan pemanfaatan sumber daya, tenaga kerja, dan teknologi lokal. Cara kerjanya adalah dengan memberikan honorarium langsung tunai kepada tenaga kerja yang terlibat melalui dana desa. Tujuannya adalah untuk memberikan tambahan upah, meningkatkan daya beli masyarakat, mengurangi kemiskinan, dan mendukung penurunan angka stunting.

Di tengah pandemi COVID-19, PKT berperan sebagai bentuk perlindungan sosial dan stimulus ekonomi oleh pemerintah bagi masyarakat (Kementerian Pekerjaan Umum dan Perumahan Rakyat Republik Indonesia, 2020). Ada juga Program Keluarga Harapan (PKH) dan Kartu Sembako guna membantu keluarga rentan miskin, pekerja sektor informal, dan pekerja harian untuk memenuhi kebutuhan dasar seperti pangan (Kompas, 2020). Dilansir dari laman resmi Kementerian Keuangan Republik Indonesia, selama pandemi COVID-19, PKH telah disalurkan kepada 10 juta Keluarga Penerima Manfaat (KPM) dengan anggaran total meningkat dari Rp 29,13 triliun menjadi Rp 37,4 triliun. Kartu Sembako 
juga diberikan kepada 20 juta KPM dengan dana sebesar Rp 200.000/KPM/bulan (Maret-Desember). Jumlah ini meningkat dibandingkan sebelumnya dimana jumlah penerima Kartu Sembako tercatat sebanyak 15,2 juta KPM seharga Rp 150.000/KPM/bulan (JanuariFebruari). Pemerintah juga mengalokasikan dana sebesar Rp 8,6 triliun untuk subsidi pajak penghasilan ( $\mathrm{PPh}$ ) yang selama ini dibayar oleh wajib pajak karyawan di industri pengolahan (Ihsanuddin, 2020).

Melalui pemberian dana langsung tunai, subsidi, pengurangan pajak, dan lain sebagainya, daya beli/ konsumsi masyarakat diharapkan dapat meningkat. Hal ini dapat dianalisis dengan melihat rumus disposable income (Yd) dan rumus personal income (PI).

$$
\begin{gathered}
\mathrm{PI}=\mathrm{NNI}+\mathrm{TF}-(\mathrm{LT}+\mathrm{PP}+\mathrm{A}+\mathrm{JS}) \\
\mathrm{Yd}=\mathrm{PI}-\text { Personal Tax }(\mathrm{PPh})-\text { Non Tax Payment }
\end{gathered}
$$

Berdasarkan rumus di atas, pemberian dana dari pemerintah (TF) akan meningkatkan personal income (PI). Peningkatan PI yang dibarengi dengan subsidi $\mathrm{PPh}$ akan meningkatkan disposable income ( $\mathrm{Yd}$ ). Harapannya, keinginan konsumsi masyarakat akan meningkat. 
Keputusan pemerintah untuk mengambil kebijakan PKT, PKH, dan subsidi PPh merupakan sebuah pilihan rasional. Apabila dibandingkan dengan kebijakan lain, misalnya pemotongan Pajak Pengusaha Kena Pajak (PKP), tiga kebijakan tersebut lebih menguntungkan pemerintah. Sebab, kebijakan-kebijakan tersebut mampu menjadi stimulus untuk meningkatkan indikator pengeluaran pemerintah (G) sekaligus menjadi stimulus konsumsi (C). Sementara itu, kebijakan pemotongan PKP hanya mampu menjadi stimulus konsumsi (C) saja dengan mekanisme trickle down effect (Aghion \& Bolton, 1997).

\section{DOMINASI EKONOMI TERHADAP SEKTOR KESEHATAN}

Menurut Juru Bicara Pemerintah untuk Penanganan COVID-19, Wiku Adisasmito, vaksin COVID-19 harus melalui beberapa tahapan terlebih dahulu sebelum memasuki tahap produksi massal (Komite Penanganan COVID-19 dan Pemulihan Ekonomi Nasional, 2020). Pada tahap penelitian dasar, peneliti menelusuri mekanisme potensial berdasarkan ilmu yang biasa dipakai. Ilmu yang akan dipakai dalam suatu tahap penelitian, sebagaimana diungkapkan oleh Ricardo Hausmann (2016: 13) adalah salah satu unsur dari 
ekonomi. Dengan demikian, dalam tahap awal proses produksinya saja, vaksin tidak bisa lepas dari ekonomi.

Dalam tahap-tahap selanjutnya, yaitu tahap uji praklinis dan klinis, vaksin melalui berbagai proses yang lebih kompleks lagi. Meminjam analogi dari Leonard E. Read (2015), vaksin pastinya telah melalui proses produksi yang kompleks-atau justru lebih kompleks lagi-seperti sebuah pensil. Read juga menyebutkan bahwa dalam sebuah proses produksi yang kompleks, keterlibatan pasar tidak dapat dihindari. Dengan demikian, vaksin yang kompleksitas pembuatannya melebihi sebuah pensil pasti banyak melibatkan mekanisme pasar dalam proses produksinya. Argumen ini diperkuat dengan proses produksi massal vaksin COVID-19 di Indonesia yang rencananya akan diproduksi oleh Perusahaan Sinovac Biotech dari Cina. Keberadaan sebuah korporasi mengindikasikan keterlibatan pasar dalam produksi vaksin dan keterlibatan pasar menunjukkan adanya proses ekonomi yang berjalan. Pilihan untuk memesan vaksin dari korporasi tersebut merupakan sebuah pilihan yang rasional. Sebab, dengan segala kompleksitasnya, vaksin akan tetap memerlukan keterlibatan pasar dalam proses produksinya. 


\section{KESIMPULAN}

Berdasarkan paparan di atas, rasionalitas prioritas kebijakan pemerintah Indonesia di masa krisis akibat pandemi bertumpu pada kalkulasi bahwa jika perekonomian pulih maka sektor lain, termasuk kesehatan, akan ikut pulih. Dalam artikel ini, PDB digunakan sebagai indikator untuk mengukur perekonomian. Shock apa pun yang berdampak kepada perekonomian, yang dapat diamati dari perhitungan PDB, akan memengaruhi kesejahteraan hidup masyarakat luas. Melihat hal ini, organisasi dunia dan pemerintah, baik secara langsung maupun tidak langsung, memilih untuk mengutamakan perekonomian dibandingkan kesehatan melalui berbagai kebijakan dan regulasi atau deregulasi yang dikeluarkan. Lebih lanjut, artikel ini diharapkan mampu membuka peluang bagi penelitian lain untuk mengeksplorasi lebih dalam dampak prioritas kebijakan ekonomi di tengah krisis pandemi terhadap legitimasi pemerintah. 


\section{REFERENSI}

Afriyadi, A. D. (2020). Tembus Rekor! 46 Perusahaan Raksasa Bangkrut Gara-gara

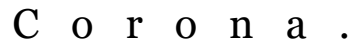
Detikfinance. Diakses dari https://finance.detik. com/berita-ekonomi-bisnis/d-5227789/coronajahat-ini-daftar-perusahaan-ritel-yang-gulungtikar/2.

Aghion, P., \& Bolton, P. (1997). A Theory of Trickle-Down Growth and Development. The Review of Economic Studies, 64 (2), 151-172. Diakses dari https://academic. oup.com/restud/article-abstract/64/2/151/1580865.

Akhlas, A. W. (2020). Indonesia's Economy to Grow in 2021 but Poverty, Unemployment to Remain High. The Jakarta Post. Diakses dari h t t p s : / / www.thejakartapost.com/news/2020/11/23/ indonesias-economy-to-grow-in-2021-but-povertyunemployment-to-remain-high.html.

Asia Perspective. (2020). Indonesia Economic Update Report This Issue: Indonesia's Economic Growth in Q1 Indonesia Signs Government Act to Tackle COVID-19. Asiaperspective. net. Diakses dari https://asiaperspective.net/ap17/ wp-content/uploads/2020/o5/indonesia-economicreport-2020Q1.pdf. 
BBC. (2020). New Zealand Lifts All Covid Restrictions, Declaring the Nation Virus-Free. $\begin{array}{llllll}B & b & c & & c & o\end{array}$ Diakses dari https://www.bbc.com/news/worldasia-52961539.

BEA. (2020). Gross Domestic Product, Third Quarter 2020 (Advance Estimate). Bea.gov. Diakses dari from https://www.bea.gov/news/2020/gross -domesticproduct-third-quarter-2020-advance-estimate.

CNN Indonesia. (2020). Kunjungan ke Mall dan Restoran Mulai Naik saat PSBB Transisi. CNN Indonesia. Diakses dari https://www.cnnindonesia.com/eko nomi/20201222121558-92-585152/kunjungan-kemal-dan-restoran-mulai-naik-saat-psbb-transisi.

Direktorat Jenderal Perimbangan Keuangan Kementerian Keuangan Republik Indonesia. (n.d.). Padat Karya Tunai. Djpk.kemenkeu.go.id. Diakses dari http:// www.djpk.kemenkeu.go.id/?ufaq=apakah-yangdimaksud-dengan- skema-padat-karya-tunai-2.

Dunford, D., Dale, B., Stylianou, N., Lowther, E., Ahmed, M., \& Arenas, I. d. l. T. (2020). Coronavirus: The World in Lockdown in Maps and Charts. Bbc.com. Diakses dari https://www.bbc.com/news/world-52103747.

Garrett, T. A. (2007). Economic Effects of the 1918 Influenza Pandemic Implications for a Modern-day Pandemic. Federal Reserve Bank of St. Louis. 
Hausmann, R. (2016). Economic Development and the Accumulation of Know-How. Welsh Economic Review. https://orca.cf.ac. uk / 92097 / 1/ Hausmann\% 2 o economic\% 20 development.pdf.

Hendartyo, M. (2020). Sri Mulyani Perkirakan Pertumbuhan Ekonomi Kuartal IV $2020 \quad-0,9$ Persen. Tempo.com. Diakses dari https://bisnis. tempo.co/read/1416463/sri-mulyani-perkirakanpertumbuhan-ekonomi-kuartal-iv-2020-09-persen/ full\&view $=$ ok.

Ihsanuddin. (2020).

9 Kebijakan Ekonomi Jokowi di Tengah Pandemi COVID-19: Penangguhan Cicilan hingga Relaksasi Pajak. Kompas.com. Diakses dari https://nasional. kompas.com/read/2020/03/26/o7412441/9kebijakan- ekonomi-jokowi-di-tengah-pandemiCOVID-19-penangguhan-cicilan?page=all. 
Ihsanuddin. (2020). Jokowi Ingatkan Bahaya jika Dahulukan Ekonomi ketimbang $\mathrm{K}$ e $\mathrm{s}$ e $\mathrm{h}$ a $\mathrm{t}$ a $\mathrm{n}$ Artikel Jokowi Ingatkan Bahaya jika Dahulukan Ekonomi ketimbang Kesehatan. Kompas.com. Diakses dari https://nasional.kompas.com/ $\mathrm{read} / 2020 / 09 / 07 / 10514071 /$ jokowi-ingatkanbahaya-jika-dahulukan-ekonomi-ketimbangkesehatan.

Investopedia \& Barnier, B. (2020). Purchasing Managers' Index (PMI). Investopedia.com. Diakses dari https://www.investopedia.com/terms/p/pmi.asp.

Jayani,D.H.(2019).Konsumsi Rumah Tangga Menyumbang 56,82\% PDB. Katadata.co.id. Diakses dari https:// databoks.katadata.co.id/datapublish/2019/05/06/ konsumsi-rumah-tangga- menyumbang-5682-pdb.

Kementerian Keuangan Republik Indonesia. (2020). PKH dan Kartu Sembako Penuhi Kebutuhan Dasar Masyarakat Rentan Miskin Terdampak COVID-19. Kemenkeu.go.id. Diakses dari https://www. kemenkeu.go.id/publikasi/berita/pkh- dan-kartusembako-penuhi-kebutuhan-dasar-masyarakatrentan-miskin-terdampak-COVID-19/. 
Kementerian Koordinator Bidang Pembangunan Manusia dan Kebudayaan Republik Indonesia. ( 20020 ) . Pembatasan Sosial Berskala Besar. Kemenkopmk. go.id. Diakses dari https://www.kemenkopmk.go.id/ pembatasan-sosial-berskala-besar.

Kementerian Pekerjaan Umum dan Perumahan Rakyat Republik Indonesia. (2020). Padat Karya Tunai: Solusi Hadapi Ketidakpastian Ekonomi di Masa Pandemi. Direktorat Pengembangan Kawasan Permukiman. Diakses dari http://sim.ciptakarya. pu.go.id/sipkp/berita/p/padat-karya-tunai-solusihadapi-ketidakpastian-ekonomi-di-masa-pandemi.

Komite Penanganan COVID-19 dan Pemulihan Ekonomi Nasional. (2020). Tahap- tahap Pengembangan Vaksin COVID-19 hingga Produksi Massal. Diakses dari https://covid19.go.id/p/berita/tahap-tahappengembangan-vaksin- COVID-19-hinggaproduksi-massal.

Kompas. (2020). Posisi Investasi Internasional Indonesia Turun, Ini Sebabnya. Kompas.com. Diakses dari ht tp s : / / money.kompas.com/read/2020/o6/26/143500326/ posisi-investasi-internasional-indonesia-turun-inisebabnya. 
Kompas. (2020). Mal Dibuka Kembali, Bangkitkan Ekonomi atau Menaikkan Kurva Pandemi? Kompas. com. Diakses dari https://properti.kompas.com/ $\mathrm{read} / 2020 / 05 / 28 / 220208521 / \mathrm{mal}$-dibuka-kembalibangkitkan-ekonomi-atau-menaikkan-kurvapandemi.

Kompas. (2020). 9 Kebijakan Ekonomi Jokowi di Tengah Pandemi COVID-19: Penangguhan Cicilan hingga Relaksasi Pajak. Kompas. com. Diakses dari https://nasional.kompas. com/read/ $2020 / 03 / 26 / 07412441$ / 9kebijakan- ekonomi-jokowi-di-tengah-pandemiCOVID-19-penangguhan-cicilan?page=all.

Kompas. (2020). UPDATE 18 Mei: 205 Perusahaan di Jakarta Disegel karena Langgar PSBB. Kompas. com. Diakses dari https://megapolitan.kompas. $\mathrm{com} / \mathrm{read} / 2020 / 05 / 19 / 12020961 /$ update-18mei-205- perusahaan-di-jakarta-disegel-karenalanggar-psbb?page $=$ all .

Kydd, A. H. (2008). Methodological Individualism and Rational Choice. In The Oxford Handbook of International Relations (1st ed.). Oxford University Press. 
Loayza, N.V., \& Pennings, S. (2020). Macroeconomic Policy in the Time of COVID-19: A Primer for Developing Countries Research \& Policy Briefs. Washington, D.C.. World Bank Group. http://documents. worldbank.org/curated/en/951811585836124198/ Macroeconomic-Policy-in-the-Time-of-COVID-19-APrimer-for-Developing-Countries

Mankiw, N. G. (2009). Macroeconomics. Worth Publishers. Maskur, F. (2020 \). Pasar Tradisional Dianjurkan Beroperasi di Masa COVID-19, Ini Ketentuannya . Bisnis.com. Diakses dari https://ekonomi.bisnis. $\mathrm{com} / \mathrm{read} / 20200503 / 12 / 1235599 /$ pasar-tradisionaldianjurkan-beroperasi-di-masa-COVID-19-iniketentuannya.

My Pivots. (n.d.). Definition of 'Global Composite PMI'. Mypivots.com. Diakses dari https://www.mypivots. com/dictionary/definition/75o/global-compositepmi.

Nazzala,

A. (2020). Klaster Rumah

Makan Semarang, 20 Orang Positif COVID-19. Bisnis.com. Diakses dari https:// semarang.bisnis.com/read/20200912/535/129066o/ klaster-rumah-makansemarang-20-orangpositif-covid-19?utm_source=Desktop\&utm _ medium=Artikel\&utm_campaign=BacaJuga_1. 
Pangaribowo, W. S., \& Kontributor Yogyakarta. (2020). Jumlah Pengunjung $\quad \mathrm{M}$ a $\mathrm{l}$ i o b o r o Berangsur Normal Seperti Sebelum Pandemi. Kompas.com. Diakses dari https://travel.kompas. $\mathrm{com} / \mathrm{read} / 2020 / 08 / 29 / 175034627 / \mathrm{jumlah}$ pengunjung- malioboro-berangsur-normal-sepertisebelum-pandemi.

Pangaribowo, W. S., \& Kontributor Yogyakarta. (2020). Kasus COVID-19 Ditemukan di Warung Bakmi di Yogyakarta, 7 Orang Positif Corona. Kompas. com. Diakses dari https://regional.kompas. com/read/2020/11/18/17381671/kasus-COVID-19ditemukan-di-warung-bakmi-di-yogyakarta-7-orangpositif.

Pinandita, A. (2020). 'New Normal' Aims to Keep Economy Running: Minister. The Jakarta Post. Diakses dari https://www.thejakartapost.com/ news/2020/05/29/new-normal-aims-to-keepeconomy-running-minister.html.

Pink, B. (2020). Konsumsi Rumah Tangga Tumbuh Negatif 5,51\% yoy di Kuartal II- 2020, Simak Pemicunya. Nasional.kontan.co.id. Diakses dari h t tp s : / / nasional.kontan.co.id/news/konsumsi-rumahtangga-tumbuh-negatif-551-yoy-di-kuartal-ii-2020simak-pemicunya. 
PwC China. (2020). China Economic Quarterly Q2/Q3 2020. PwC China. Diakses dari https://www.pwecn. com/en/research-and-insights/china-economicquarterly-q2q3-2020.html.

PwC China. (2020). The Economy has Gradually Recovered from the Covid-19 Pandemic with $3.2 \%$ Growth in Q2. It is Expected to Return to a Relatively Normal State in Q3. Pwccn.com. Diakses dari https:// www.pwccn.com/en/research-and-insights/chinaeconomic-quarterly-q2q3-2020.html.

Read, L. E. (2015). I, Pencil. Foundation for Economic Education. https://fee.org/media/14940/read-ipencil.pdf.

Satyagara. (2020). Sri Mulyani Sebut Peningkatan Belanja Negara Momentum Dongkrak Ekonomi. Antaranews.com. Diakses dari https: / / w w . antaranews.com/berita/1740377/sri-mulyani-sebutpeningkatan-belanja-negara-momentum-dongkrakekonomi.

Sembiring, L. J. (2020). Nilai Ekspor April 2020 Turun 7,02\%, Impor Anjlok Hingga 19\%. Cnbcindonesia. com. Diakses dari https://www.cnbcindonesia. com/news/20200515090453-4-158682/nilai-eksporapril-2020-turun-702-impor-anjlok-hingga-19. 
Sentix. (n.d.). Sentix Sentiment Index. Sentix.de. Diakses dari https://www.sentix.de/index.php/en/item/ sntm.html.

Setiati, S., \& Azwar, M. K. (2020). Dilemma of Prioritising Health and the Economy During C O V I D - 19 Pandemic in Indonesia. Acta Medica Indonesia, 52. https://www.actamedindones.org/index. php/ijim/article/view/1579.

Stats NZ. (2020). Gross Domestic Product: September 2020 Quarter. Stats.govt.nz. Diakses dari https://www. stats.govt.nz/information-releases/gross-domesticproduct-september-2020-quarter.

Sugianto, D. (2020). Bos BI Yakin Ekonomi RI Kuartal IV - 2020 Positif, Tapi Kecil B a n g e t . Detikfinance. Diakses dari https://finance.detik. com/moneter/d-5285019/bos-bi-yakin-ekonomi-rikuartal-iv-2020-positif-tapi-kecil-banget.

Syauqi, A. (2020). Tracing Kasus Corona di Warung Makan Klaten, Ditemukan 21 Kontak Erat. News.detik. com. Diakses dari from https://news.detik.com/ berita-jawa-tengah/d-5198777/tracing-kasus-coronadi-warung-makan-klaten-ditemukan-21-kontak-erat. 
Trading Economics. (2020). Indonesia Foreign Direct Investment 2010-2020 Data | 2021-2022 F o r e c a s t | Calendar. Tradingeconomics.com. Diakses dari https://tradingeconomics.com/indonesia/foreigndirect-investment\#: :text=Foreign \%2oDirect\%2oInvestment\%20in\%2oIndonesia,the\%2ofirst\%20 quarter\%20of\% 202010.

Trading Economics. (2020). Indonesia - Pertumbuhan PDB (y-on-y). Tradingeconomics.com. Diakses dari https://id.tradingeconomics.com/indonesia/gdpgrowth-annual.

Trading Economics. (2020). Taiwan GDP Growth Rate. Tradingeconomics.com. Diakses dari https:// tradingeconomics.com/taiwan/gdp-growth.

Victoria, A. O. (2020). 29 Juta Pekerja Terdampak COVID-19: Jam Kerja Berkurang hingga PHK. Katadata.co.id. Diakses darihttps://katadata.co.id/ agustiyanti/finansial/5fa39e64a3boe/29-jutapekerja-terdampak-COVID-19-jam-kerja-berkuranghingga-phk.

Weible, Christopher et al. (2020). COVID-19 and the Policy Sciences: Initial Reactions and Perspectives. Policy Sciences. 53. 10.1007/s11077-020-09381-4. 
World Bank. (2020). The Global Economic Outlook During the COVID-19 Pandemic: A C h a nge d World. Worldbank.org. Diakses dari https:// www.worldbank.org/en/news/feature/2020/o6/o8/ the-global-economic- outlook-during-the-COVID-19pandemic-a-changed-world.

World Bank. (2020). Global Monthly November 2020. Worldbank.org. Diakses dari http://pubdocs. worldbank.org/en/174391606322864876/GlobalMonthly-Nov20.pdf.

World Bank. (2020). Indonesia Economy Prospects: The Long Road to Recovery. The World Bank.

World Health Organization. (2020). WHO Coronavirus Disease (COVID-19) Dashboard. Covid19.who.int. Diakses dari https://covid19.who.int.

World Health Organization. (2020). Listings of WHO's Response to COVID-19. Who.int. Diakses dari https://www.who.int/news/item/29-06-2020covidtimeline.

Worldometer. (2020). Indonesia Coronavirus Cases. Worldometers.info. Diakses dari https:// www . worldometers.info/coronavirus/country/indonesia/.

Zaprulkhan. (2018). Filsafat Modern Barat: Sebuah Kajian Tematik. IRCiSoD. 